\title{
Agenda Pembaharuan Hukum Ekonomi Indonesia Menyongsong Abad XXI
}

\author{
Erman Rajagukguk
}

embaharuan hukum yang berkaitan dengan kegiatan ekonomi adalah untuk mencapai "predictability" (kepastian), "fairness" (keadilan) dan "efficiency" (efisiensi). Bahkan dalam era globalisasi ekonomi sekarang ini ketiga unsur tersebut menjadi kian bertambah penting berdasarkan alasan-alasan yang akan dikupas lebih lanjut dalam uraian ini.

Pembangunan suatu bangsa sedikitnya melalui tiga tingkatan, yaitu tingkat mencapai persatuan dan kesatuan nasional (unifikasi), tingkat industrialisasi yang ditandai dengan akumulasi modal dan pembentukan manajer-manajer untuk mendo- rong pertumbuhan ekonomi dan tingkat ketiga, Negara Kesejahteraan, di mana pekerjaan utama Pemerintah adalah melindungi mereka yang menderita akibat berkembangnya industrialisasi. Indonesia seperti negara-negara berkembang lainnya harus mencapai ketiga tingkatan tersebut sekaligus, bukan tahap demi tahap, seperti yang terjadi sebelumnya pada negaranegara yang sekarang disebut "Developed" Countries". Kebijaksanaan pembaharuan hukum ekonomi Indonesia dalam era globalisasi ekonomi sekarang ini dan dalam menghadapi kecenderungan pasar bebas, hendaknya berorientasi pada tetap di- jaganya persatuan bangsa, mendorong pertumbuhan ekonomi dan dalam waktu bersamaan melindungi pihak yang lemah dari sisi negatif industrialisasi. Ketiga orientasi tersebut mesti tercermin dalam pembaharuan peraturan perundang-undangan, sikap tindak aparatur dan persepsi masyarakat Indonesia terhadap hukum.

\section{Pembaharuan Peraturan Perundang-undangan}

Berdasarkan sasaran pembangunan bidang ekonomi yang telah diuraikan di atas, maka program legislasi nasional di masa datang ini perlu memberikan prioritas pada undang-undang yang berkaitan dengan akumulasi modal untuk pembiayaan pembangunan dan demokratisasi ekonomi untuk mencapai efisiensi serta perlindungan bagi masyarakat golongan kecil.

Pertama, optimalisasi sumber pembiayaan pembangunan dengan jalan melaksanakan ketentuan dari Undang-Undang tentang Jaminan, Undang-Undang Pasar Modal, Undang-Undang Perbankan, Undang-Undang Perseroan Terbatas yang baru, pembentukan Undang-Undang mengenai Leasing, Sewa Beli, Factoring, Modal Ventura. 
Topik: Agenda Pembaharuan Hukum Ekonomi, Erman Rajagukguk

Kedua, dalam hubungan dengan demokrasi ekonomi dan perlindungan konsumen, sudah waktunya Indonesia memiliki Undang-Undang Anti Monopoli atau UndangUndang mengenai Persaingan yang jujur (competition law), Undang-Undang mengenai keterkaitan antara industri besar, menengah dan kecil (sub contracting), ketentuanketentuan yang mengatur berkembangnya sektor informal dan Undang-Undang Perlindungan Konsumen. Sektor informal telah diakui sebagai katup pengaman bagi tenaga kerja yang pindah dari sektor agraria tetapi tidak dapat ditampung oleh sektor industri, dan merupakan motor penggerak ekonomi rakyat. Perkembangan sektor informal sudah menjadi ciri yang dominan dalam perkembangan ekonomi masyarakat bahwa di dunia ketiga, sektor informal diakui pula menjadi salah satu alternatif untuk menampung tenaga kerja yang terlempar dari sektor agraris namun tidak tertampung oleh sektor industri. Melalui hukum, sektor informal ini bisa menjadi formal dalam bentuk usaha-usaha kecil. Berbagai usaha kecil ini dalam tahap berikutnya dapat terkait dengan usaha besar, yang diharapkan rezeki usaha besar akan menetes juga kepada masyarakat usaha kecil.

Untuk mengembangkannya perlu dipikirkan bentuk-bentuk perizinan khusus untuk sektor informal, fasilitas hukum dalam hubungannya dengan hak milik, kontrak, dan sebagainya.

Keterkaitan industri besar dengan industri-industri kecil, bukan saja berdasarkan belas kasihan atau alasan-alasan politis, tetapi sudah menjadi suatu keharusan karena alasan efisiensi dan teknis dalam suatu masyarakat indutri.

Dalam hubungan ini perlindungan terhadap usaha-usaha kecil perlu mendapat perhatian hukum.

Dalam kaitannya dengan perdagangan internasional untuk melindungi industri da- lam negeri, perlu pula Undang-Undang Anti Dumping.

Dalam penyusun peraturan perundangundang tersebut, sedikitnya terdapat tiga syarat yang harus dipenuhi agar undangundang yang dimaksud dapat berjalan efektif. Pertama, undang-undang harus dapat disajikan dalam bahasa yang dapat dipahami oleh masyarakat, artinya undangundang tersebut tidak bersifat simbolik, tetapi operasional. Oleh karenanya perlu lembaga legislatif mengevalusi setelah jangka waktu tertentu, apakah suatu undang-undang telah berjalan sebagaimana dimaksudkan oleh pembuatnya.

Kedua, penyusunan undang-undang hendaknya sesuai dengan aspirasi masyarakat.

Selanjutnya, suatu undang-undang adakalanya memerlukan aturan-aturan yang bersifat proseduril, agar ia dapat berjalan sesuai tujuannya.

Sedikitnya ada empat hal yang perlu diperhatikan dalam pembaharuan hukum tersebut di atas. Pertama, bagaimana hukum dapat mempengaruhi tingkat pertumbuhan ekonomi? Kedua, apa hasilnya jika kita mengimpor begitu saja peraturan perundang-undangan dari negara maju? Ketiga, bagaimana social engineering melalui peraturan perundang-undangan dapat mempengaruhi perubahan sosial. Keempat, bagaimana para sarjana hukum dan institusi hukum dapat lebih responsif terhadap kebutuhan mayoritas dari rakyat yang tidak memiliki akses yang sama dan efektif untuk mendapat keadilan dalam sistem hukum yang ada. Hal-hal ini harus dapat dijawab jika perubahan sosial dan pembangunan ekonomi hendak mencapai pertumbuhan ekonomi sekaligus perbaikan kualitas hidup dan masyarakat yang adil.

Globalisasi pasar berarti negara harus memperbaharui hukum, dengan tidak saja mempertimbangkan kepentingan perusa- 
haan-perusahaan, tetapi juga bagaimana supaya bisa sukses di pasar internasional. Kita harus menimbang-nimbang bagaimana mengakomodasi kepentingan luar negeri; sementara kebijaksanaan yang sama dapat memenuhi kebutuhan dalam negeri. Tidak ada jawaban yang sederhana. Walaupun telah terjadi globalisasi ekonomi, kita tidak boleh mengenyampingkan konstitusi, sejarah dan way of life kita sendiri.

Pembangunan secara keseluruhan berkaitan dengan ekologi, kebudayaan, sosial, ekonomi, institusi dan politik; hal tersebut hanya dapat dimengerti dalam keterkaitannya satu sama lain secara sistimatis dan integral.

Dalam hubungannya dengan peranan hukum dalam pembangunan (ekonomi) tepat apa yang dikatakan oleh Adam Smith, pencetus perdagangan bebas, bahwa "the end of justice is to secure from injury".

Oleh karenanya dalam memasuki era industrialisasi ini kita perlu memperkuat penegakan hukum dalam bidang public law, yaitu negara atas nama masyarakat perlu campur tangan untuk melindungi golongan masyarakat yang lemah.

Upah yang rendah tidak selalu berarti upah yang murah. Upah minimum yang telah ditetapkan oleh Pemerintah masih berada di bawah tingkat pemenuhan kebutuhan dasar, dan malah banyak perusahaan-perusahaan yang tidak mematuhinya, ditunjang keberadaan buruh yang tidak mempunyai organisasi buruh yang kuat sehingga tidak dapat memperjuangkan hakhaknya. Di samping itu ketatnya persaingan di pasar kerja menjadikan buruh tidak mempunyai keberanian untuk memperjuangkan perbaikan nasib mereka. Ketentuan-ketentuan Hukum Perburuhan yang bersangkutan dengan perlindungan buruh perlu mendapat pembaharuan. Sejalan dengan itu indonesia memerlukan sebuah serikat buruh yang kuat dalam memperjuangkan nasib buruh. Modal selalu berpindah ke tempat di mana ada buruh murah dan penegakan hukum perburuhan yang lunak. Inilah perlunya perlindungan bagi buruh.

\section{Perlindungan Konsumen}

Berkembangnya produk-produk industri di satu pihak memerlukan dikembangkan perlindungannya konsumen dipihak lain. Perlindungan Hukum terhadap konsumen tidak saja terhadap barang-barang berkualitas rendah tetapi juga terhadap barangbarang yang membahayakan kehidupan manusia, umpamanya makanan, minuman dan obat-obatan.

Hukum Perlindungan Konsumen di Indonesia belum berkembang mengikuti irama kemajuan produksi-produksi dunia industri.

\section{Pencemaran Lingkungan}

Pencemaran lingkungan akibat industrialisasi perlu pula mendapat perhatian yang terus menerus dan khusus. Kecenderungan untuk mengutamakan pertumbuhan industrialisasi bisa mengakibatkan perusahaan-perusahaan menolak tanggung jawab atas pencemaran lingkungan. Pengalaman dari negara-negara maju menjadi bahan pelajaran bagi kita dalam usaha menuju suatu negara industri. Ada kekhawatiran bahwa relokasi dari negara-negara maju ke negara berkembang disebabkan antara lain ketatnya penegakan hukum lingkungan di sana, sementara di negara berkembang hal itu belum terjadi. Mereka yang bergerak di bidang hukum, mempunyai tugas yang berat yaitu bagaimana hukum bisa berperanan mengatasi krisiskrisis yang terjadi dalam suatu proses industrialisasi, antara lain berkenaan dengan 
Topik: Agenda Pembaharuan Hukum Ekonomi, Erman Rajagukguk

terbuangnya sumber-sumber daya alam yang tidak dapat diperbaharui, pemilihan teknologi yang merusak keseimbangan atau yang buruk lagi teknologi tak memerlukan banyak buruh di tengah angkatan kerja yang terus melimpah dan pemerasan tenaga manusia tanpa memberikan kompensasi yang memadai.

\section{Pertanahan}

Industrialisasi dan majunya perdagangan membutuhkan tanah baik di desadesa maupun kota-kota Jawa dan luar Jawa. Masalah pertahanan semakin hari akan semakin banyak, jika hukum pertanahan kita tidak mampu memainkan peranannya. Pihak yang lemah yang sebagian besar adalah rakyat kecil akan memikul beban pembangunan tersebut. Dalam hal ini perlu diperjelas penyelesaian masalah-masalah yang bersangkutan dengan umpamanya, tanah adat, tanah negara, besarnya ganti rugi. Begitu juga perencanaan wilayah yang bersangkutan dengan tanah pertanian yang subur; daerah pemukiman, perdagangan dan industri.

Intensifikasi dan ekstensifikasi pertanian memerlukan kepastian hukum akan tersedianya atau tetap dipertahankannya lahan-lahan pertanian yang subur dari meluasnya keperluan tanah untuk industrialisasi, pemukiman, dan kebutuhan-kebutuhan lain. Beberapa Peraturan Pelaksanaan dari Undang-Undang Pokok Agraria dan Undang-Undang Penataan Ruang sudah waktunya disusun.

\section{Aparatur Hukum}

GBHN menyampaikan pesan tentang perlunya peningkatan penegakan hukum dan pembinaan aparatur hukum, sarana dan prasarana hukum. Dikatakan antara lain pembangunan aparatur hukum diarahkan pada terciptanya aparatur yang memiliki kemampuan untuk mengayomi masyarakat dan mendukung pembangunan nasional. Hal ini tepat karena peraturan perundangundangan saja tidak cukup. Perlu aparatur yang bersih dan efisien untuk melasanakan peraturan perundang-undangan tersebut. Hal ini mencakup badan yudikatif, legislatif dan eksekutif.

\section{Badan Peradilan}

Peranan pengadilan akan semakin bertambah penting di masa datang. Sebagai contoh Undang-Undang No. 1 tahun 1995 tentang Perseroan Terbatas menyebutkan sampai 12 kali keterkaitan pengadilan baik dalam memberikan penetapan maupun memutuskan perkara. Tugas hakim adalah membawa undang-undang itu kepada kenyataan sosial. Pengadilan yang bersih dan berwibawa perlu diusahakan terus. Dalam kaitan ini tidak bisa dihindarkan penambahan anggaran untuk meningkatkan kesejahteraan dan kualitas para hakim. Pengadilan yang jujur dan bersih masih jauh dari cita-cita dalam kondisi kesejahteraan hakim seperti sekarang ini. Yang memilukan, bila keputusan hakim didasarkan pada imbalan yang diterima dari pihak yang berperkara dan bukan berdasarkan faktafakta dan argumentasi hukum.

Di samping memperbaiki badan peradilan, sudah waktunya Indonesia mengembangkan penyelesaian sengketa alternatif (Alternative Dispute Resolution).

Penyelesaian sengketa alternatif sudah lama dikembangkan, baik di Barat seperti Amerika Serikat dan Norwegia maupun di Timur, seperti Jepang dan Cina, baik karena alasan-alasan praktis maupun kebudayaan. Penyelesaian sengketa mélalui Pengadilan di Barat dan di Timur mengandung kelemahan, yaitu memakan waktu yang lama dari pengadilan tingkat per- 
tama sampai tingkat banding atau kasasi, memakan biaya yang tinggi, dan merenggangkan hubungan pihak-pihak yang bersengketa. Di negara-negara berkembang, pengadilan adakalanya, dianggap perpanjangan tangan kekuasaan, bahkan di beberapa negara Pengadilan dianggap tidak bersih, sehingga putusan-putusannya dianggap telah memihak yang mendatangkan ketidakadilan.

Alasan-alasan kebudayaan, menyebabkan pula masyarakat cenderung mengenyampingkan Pengadilan sebagai tempat penyelesaian sengketa yang timbul di antara mereka. Masyarakat Timur seperti Cina dan Jepang, secara tradisional tidak suka pada Pengadilan. Pengadilan dianggap sebagai tempat orang-orang "jahat", yang tidak mematuhi hukum. Secara tradisional, orang-orang Cina dan Jepang amat segan untuk membawa sengketa-sengketa perdata mereka ke depan Pengadilan. Untuk menjaga harmoni, sengketa-sengketa perdata diselesaikan melalui mediasi (Cina dan Jepang) serta konsiliasi (Jepang). Karena alasan-alasan praktis, penyelesaian sengketa alternatif seperti arbitrase, negoisiasi, mediasi dan konsiliasi semakin berkembang di Amerika Serikat maupun di Jepang. Praktek negosiasi, mediasi, konsoliasi dan arbitrase juga sudah ada di Indonesia. Walaupun belum semua mempunyai peranan penting dalam penyelesaian sengketa di luar pengadilan.

\section{Dewan Perwakilan Rakyat}

Tiap komisi lembaga legislatif perlu dilengkapi dengan tenaga-tenaga ahli. Walaupun DPR adalah perwakilan politik, namun pengetahuan dan informasi mengenai hal-hal yang bersifat teknis perlu tersedia. Oleh karena itu tenaga ahli dari berbagai bidang perlu melengkapi DPR. Maksudnya agar DPR dapat menjalankan fungsinya dengan kualitas yang seimbang dengan eksekutif. Banyak inisiatif legislatif di berbagai negara maju dan berkembang gägal mencapai tujuannya dan yang hampir selalu disalahkan adalah segmen masyarakat, sehingga undang-undang tidak bisa dijalankan. Sebenarnya tanggung jawab kegagalan tersebut sebagian besar ada pada legislatif sendiri, karena mereka gagal menangkap aspirasi yang hidup.

Walaupun tidak ada korelasi empiris bahwa demokratisasi perlu untuk pertumbuhan ekonomi dan integrasi ke pasar dunia tidak selalu membuat pemerintah menjadi represif, bertambahnya tingkat kemakmuran masyarakat dan mengakibatkan bertambahnya keinginan bagi terciptanya masyarakat yang lebih demokratis, sehingga memungkinkan partisipasi masyarakat yang lebih luas dan besar dalam pengambilan keputusan pembangunan. Dalam kerangka tersebut perlu pembaharuan Undang-Undang Pemilihan U̇mum sehingga anggota DPR adalah wakil-wakil rái:yat berdasarkan calon yang datang dan dipilih langsung oleh rakyat. Agar supaya DPR dapat mempunyai inisiatif dan menjalankan fungsinya sesuai yang tercantum dalam Undang-Undang Dasar 1945, perlu kiranya suatu Undang-Undang tentang Tata Cata Penyusunan Undang-Undang dan UndangUndang yang menyangkut ratifikasi perjanjian-perjanjian internasional. Dalam usaḥa menjaga agar peraturan pelaksanaan tidak bertentangan dengan Undang-Undang, suatu Undang-Undang mengenai judicial review merupakan hal yang mendesak.

\section{Biro Hukum Departemen}

Perlu peningkatan kualitas tenaga-tenaga pada Biro Hukum di berbagai Departemen. Hal ini berkenaan dengan peranan hukum yang semakin meningkat dimasamasa yang akan datang, tidak saja menge- 
nai, masalah-masalah hukum lokasi, nasional, tetapi juga internasional yang terkait secara lintas sektoral.

Umpamanya, masalah pertanian tidak saja berkenaan dengan produksi, tetapi juga pemasaran bahkan industrialisasi. Hal itu tidak saja berkenaan dengan pasar dalam negeri tetapi juga luar negeri, karena Indonesia ikut dalam perdagangan internasional.

\section{Pengacara-Konsultan Hukum}

Kalangan pengacara dan pemberi bantuan hukum perlu ikut juga membenahi diri. Sarjana Hukum harus cukup memahami issue-issue ekonomi, sehingga dapat memenuhi harapan-harapan dari para perencana dan administrator. Di samping perlunya Undang-Undang Bantuan Hukum, organisasi-organisasi profesi hukum perlu menegakkan kode etik professi.

\section{Budaya Hukum}

GBHN dalam menetapkan sasaran pembangunan jangka panjang kedua bidang hukum memandang perlunya perlindungan hukum yang berintikan keadilan dan kebenaran dalam mencapai kepastian dan ketertiban. Dihubungkan dengan pembangunan. di bidang politik, maka pembangunan juga mewujudkan budaya politik keterbukaan untuk meningkatkan kualitas demokrasi.

Dalam kerangka di atas itu, GBHN memandang hukum tidak hanya sebagai serangkaian peraturan perundang-undangan yang menekankan fungsinya untuk menjaga ketertiban, tetapi juga hukum berperan untuk mengembangkan partisipasi masyarakat yang tertuang dalam hak dan kewajiban masyarakat.

Sudah jelas bahwa "budaya hukum" yang dimaksud oleh GBHN tersebut hukum "budaya hukum" masyarakat Cina atau Jepang, yang memandang hukum semata- mata sebagai serangkaian perintah segera yang harus ditaati (order), apapun isinya tetapi hukum adalah juga memuat hak-hak masyarakat (rights) dalam suatu negara. Hak-hak itu berkenaan dengan partisipasi mereka untuk ikut memutuskan hal-hal yang paling baik untuk mereka dalam proses pembangunan ini. Hal tersebut antara lain akan tercermin dalam isi UndangUndang dan Peraturan Pelaksanaannya. sikap tindak aparatur hukum dalam menjalankan fungsinya, dan ketaatan masyarakat terhadap hukum. Indonesia kini, menurut hemat saya, dalam masa transisi.

Sebagian masih terikat kepada nilainilai budaya lama yang paternalistis, sebagian lainnya mendorong berkembangnya nilai-nilai baru menuju masyarakat yang lebih terbuka dan lebih demokratis. Dalam masa transisi tersebut, pada kasus-kasus tertentu ada kalanya terjadi tarik menarik antara nilaj-nilai lama dan nilai-nilai baru. $\mathrm{Hal}$ ini bukanlah suatu yang aneh karena legal cuture itu adalah bagian dari kebudayaan suatu bangsa, dan legal culture tersebut, menurut friedman tergantung kepada sub-legal culture anggota-anggota masyarakatnya, yaitu tergantung kepada posisinya dalam masyarakat, latar belakang kebudayaan, politik, paham yang dianutnya, serta pendidikan yang mereka terima: Dalam konteks ini, pembaharuan hukum menuju masyarakat yang lebih terbuka dan lebih demokratis bukan suatu pekerjaan yang mudah.

\section{Penutup}

Pembangunan ekonomi untuk dapat behasil perlu mendapat dukungan dari sistem hukum. Bahkan ada yang berpendapat bahwa kerangka hukum yang efektif adalah prasyarat bagi pembangunan ekonomi yang bertujuan mencapai kesejahteraan bagi semua lapisan masyarakat. Sistem hukum 
Topik: Agenda Pembaharuan Hukum Ekonomi, Erman Rajagukguk

di Indonesia tidak dapat bekerja, tanpa adanya pembaharuan substansi peraturan perundang-undangan, perbaikan aparatur hukum dan perubahan pandangan negara dan masyarakat mengenai peranan hukum dalam kehidupan berbangsa dan bernegara.

\section{Kepustakaan}

Barenberg, Mark. "Law and Labor in the New Global Economy: Through the Lens of United States Federalism," Columbia Journal of Transnational Law. Vol. 33 (1995).

Breeden, Richard C. "The Globalization of Law and Business in the 1990s," Wake Forest Law Review, vol. 28, No. 3 (1993).

De Graaf, Gerard and King, Matthew. "Towards a More Global Government Procurement Market: The Expansion of the GATT Government Procurement Agreement in the Cobtext of the Uruguay Round"' The International Lawyer, vol. 29, No. 2 (Summer 1995).

De Wet, Erika "Labor Standards in the Globalized' Economy: the Inclusion of a Social Clause in the General Agreement On Tariff and Trade/ World trade Organization," Human Rights Quaterly, vol. 17 (1995).

Delors, Jaques "The Future of Free Trade in Eurape and the World," Fordham International Law Journal, vol. 18 (1995).

Demaret, Paul "The Metamorphoses of the GATT: from the Havana Charter to the World Trade Organization," $\mathrm{Co}$ Iumbia Journal og Transnational Law, vol . 34 (1995).

Friedman, Lawrence M. A History of American Law, (New York: Simon and Schuster, 1973).
Frank, Thomas M. "The New Development: Can American Law and Legal Institutions Help Developing Countries" Wisconsin Law Review No. 3 (1972). Footer, Mary E. "The International Regulation of Trade in Services Following Completion of the Uruguay 'Round, "The International Lawyer, Vol. 29, No. 2 (Summer 1995).

Garis-Garis Besar Haluan Negara 1993.

Green, Carl J. "APEC and Trans - Pacific Dispute Management. "Law and Policy in International Business," Vol. 26 (1995).

Gomes, Malrio "Social Economic Rights and Human Rights Commissions," Human Ringhts Quaterly vol. 17 (1994).

Geist, Michael A. "Toward A General Agreement on the Regulation of Foreign Direct Investment," Law \& Policy in International Business," vol. 26 (1995).

Gray, Whitmore "Globalization of Contract Law: Rules for Commercial Contracts in the 21st Century," New Zealand Law Journal (Febr. 1996).

Hasibuan, Sayuti. Ekonomi Sumber Daya Manusia (Jakarta: LP3ES, 1996).

Hufbauer, Bary "International Trade Organization and Economies in Transition: A Glimpse of Twenty - First Century," Law \& Policy in International Business, vol. 26 (1995).

Howse, Robert and Trebilcock, Michael J. "The Fair Trade - Free Trade Debate: Trade, Labor, and the Environment," International Review of Law and Economics, No. 16 (1996).

Kartasasmita, Ginanjar. Pembangunan untuk Rakyat, Memadukan Pertumbuhan dan Pemerataan. (Jakarta: CIDES, 1996).

Manique, John O. : Human Right and Development, "Human Ringhts Quaterly 
Topik: Agenda Pembaharuan Hukum Ekonomi, Erman Rajagukguk

vol. 14 (1992).

Mendelson, Wallace "Law and the Development of Nations," The Journal of Politics. vol. 32 (1970).

Organski, A.F.K. The Stages of Political Development (New York: Knoff, 1965).

Osinbajo, Yemi -Ajayi, Olukonnyisola. "Human Rights and Economic Development in Developing Countries," The International Lawyer, vol. 28 No. 3 (1994).
Stutzman, Andrew K. "Our Eroding Industrial Base: U.S. Labor Laws Compared with Labor Laws of Less Developed Nations in Light of the Global Economy," Dickenson Journal of International Law No. 12 (Fall 1993). Theberge, Leonard J. "Law and Economic Development," Journal of International Law and Policy. vol. 9 (1980).

Upham, Frank K. Law and Social Change in Postwar Japan, (Cambridge: Hanvard University, 1987).

Undang-Undang Dasar 1945 (UUD' 45). 